\title{
Current Trends, Challenges and Prospects for the Yenisei Arctic Development
}

\author{
Olga V. Shulepova* \\ Siberian Federal University \\ 79 Svobodny, Krasnoyarsk, 660041, Russia
}

Received 15.05.2018, received in revised form 31.08.2018, accepted 07.09.2018

The article is devoted to the analysis of the core studies, legal framework and trends related to the spatial development of the Arctic zone of the Krasnoyarsk Krai, one of the most important strategic regions of the Russian Federation. A large number of modern academic studies related to the most important socio-cultural and socio-economic factors that determine the Yenisei Arctic development has been analyzed in the article. The concept of the "Yenisei Arctic" has been developed for the first time. The time range of the analyzed scientific and normative literature is 2008-2018. Thus, the article presents the most relevant materials related to the development trends of one of the most important projects of the modern Krasnoyarsk Krai-the Yenisei Siberia.

The purpose of the study is to identify the vectors of academic science related to the Yenisei Siberia, to substantiate the use of the concept of "the Yenisei Siberia".

The article may be of interest to a wide range of modern researchers, it affects not only such a field of science as culturology, but also several other areas of scientific disciplines, such as economics, political science and sociology.

The conclusion contains the summary of the most promising lines of the Yenisei Arctic research, the most important conceptual and methodological approaches that can be used to solve academic problems are revealed.

Keywords: the Yenisei Siberia, the Yenisei Arctic, conceptions, methods, academic research, legal framework.

Research area: culturology.

Citation: Shulepova, O.V. (2018). Current trends, challenges and prospects for the Yenisei Arctic development. J. Sib. Fed. Univ. Humanit. soc. sci., 11(9), 1499-1512. DOI: 10.17516/1997-1370-0318.

\section{Introduction}

Nowadays the importance of the Arctic is greatly increasing. It is becoming a space of the closest attention of countries and peoples both as a region which well-

(C) Siberian Federal University. All rights reserved

* Corresponding author E-mail address: shulepova@rambler.ru

This work is licensed under a Creative Commons Attribution-NonCommercial 4.0 International License (CC BY-NC 4.0). 
being largely determines the climate of the planet, and as a treasure trove of unique nature, as well, of course, as a territory with enormous economic opportunities and huge economic potential ${ }^{1}$.

The Russian North occupies about $2 / 3$ of the country's territory. Only $7.4 \%$ of the population lives in the Arctic regions, but it is they who produce most of the gross domestic product and account for $66 \%$ of all foreign currency return, $93 \%$ of Russian natural gas production and $75 \%$ of oil, which are the main export positions of the Russian economy. $80 \%$ of the country's mineral resources are concentrated in the Arctic zone of Russia, $100 \%$ of Russian diamonds, more than $90 \%$ of nickel and cobalt, $96 \%$ of platinum, $63 \%$ of gold and $60 \%$ of copper are mined there, it is the source of $50 \%$ of commercial timber and $68 \%$ of fish.

However, the development of the Arctic zone of the Russian Federation is, first of all, the development of the territories of its constituents, as well as the adjacent areas. This article attempts to understand the processes taking place in the Far North of the Russian Federation through socio-economic transformations in the Yenisei Arctic.

\section{Russian North at the Current Stage of Development}

Already in 1911, the outstanding researcher of the North A.V. Rusanov attached great importance to the development of the Northern Sea Route, primarily as a transport artery connecting western and eastern borders of the country, as well as the one connecting Russia with the outer world: “... Russia faced an immense historical task, and if this task is solved, if we find a way out to hundreds of millions of poods of Siberian goods using the cheapest Northern Sea Route, then we will conquer the world market. This bloodless, purely economic conquest is immeasurably more important than the most brilliant military victory, since economic domination is the most solid basis of political power. And I would consider the goal achieved if my call for the conquest of ice implied something more: a call to conquer the world market, a call to the might and glory of Russia ... the Northern Sea Route is the only way to conquer the world market by Russia"2.

Nowadays, according to calculations by the Ministry of Transport of the Russian Federation, the cargo traffic of the Northern Sea Route will increase to 64 million tons

Vladimir Putin's Speech at "The Arctic: Territory of Dialogue" International Forum (2017). Available at: http:// forumarctica.ru/news/vystuplenie-vladimira-putina-na-mezhdunarodnom-forume-arktika-territoriya-dialoga/

2 Zhilinsky, A.A. (1919). The Far North of European Russia. Arkhangelsk Province. Petrograd, Typo-Lithography of the North-Zaadny District of Railways, 296 p. 
by 2020 , and to 85 million tons by 2030 . For comparison, in 2008 the cargo traffic along the Northern Sea Route was 1.8 million tons.

Therefore, it is not surprising that the Arctic has become one of the priority areas of social and public research both in Russia and other countries.

In the recent past, the state policy towards the Far North was characterized by the concepts of "conquest", "occupation" and "development". Today, the task is to create modern civilized working and living conditions for people. Currently 2.5 million Russians consider the Arctic their home. One of the topics at the Krasnoyarsk Economic Forum in April 2018 was Comfortable Living Environment in the Arctic. The Expert Declaration notes: "The Russian North is a unique, close-knit community of people living at the limits of human abilities, that has formed a unique way of life, where the values of cognition, mutual assistance and the value of life itself are brought to a higher limit (Anderson, 1996, 2000, Forsyth, 1994).

Generations of Russians, often against their own free will, devoted their lives and health to give the untold riches of the North to the future generations.

The key issue of social, economic and environmental policy in the $21^{\text {st }}$ century is how to ensure decent working conditions and comfortable living conditions for the people inhabiting the cities of the Russian North..."'.

On August 25, 2016 the implementation plan for the third stage of the Concept for the Sustainable Development of Indigenous Peoples of the North, Siberia and the Far East was approved. It includes a set of measures aimed at preserving the traditional habitat of indigenous small-numbered peoples, their way of life, modernization of economic activities and the entire social sphere (including the system of education, health care and culture) in the places of their traditional residence.

Contact with the developed industrial society has broken the delicate balance of the northern world. The working and living conditions of the local population have deteriorated in the areas of residence of the indigenous small-numbered peoples of the North, the ecological balance of the territory has been violated, the lands of traditional nature management has been alienated for industrial use, which leads to the loss of traditional types of management, culture and native languages, has an extremely adverse effect on the health of indigenous small-numbered peoples of the North and creates problems in the sphere of labor activity.

Comfortable Living Environment in the Arctic. Expert Declaration COMFORTABLE ARCTIC (2018). In Krasnoyarsk Economic Forum. Available at: http://porarctic.ru/proyekt-ekspertnoy-deklaratsii-komfortnayaarktika/ 
However, Krasnoyarsk scientists note that: “... national consciousness and selfidentification of the representatives of indigenous small-numbered peoples is at a high degree of development and determinancy, indicating to patriotism in relation to the native territory and the traditional way of life ... It can be said that the social picture of the indigenous communities of the North is a social organism striving for self-government, and the current foundation of its existence is forming an indigenous national lifestyle in accordance with the traditions, but integrated into modern processes, while the vector of movement is the solution of national problems of the peoples of the North under the leadership of the national elite - the activists"

In connection with the growing environmental threats worldwide, an important role is given to the ecological potential of the Northern Territories. The Russian Arctic is about a third of the ecologically clean territory of the globe. It not only plays a role in the production of oxygen needed by the whole planet, but it is also a region where a significant amount of fresh drinking water is concentrated.

At the beginning of 2012 there were 450 specially protected natural areas in the Arctic region of Russia with a total area (excluding marine areas) of slightly more than 94.6 million hectares, which is about $16.2 \%$ of the total area of the Russian Arctic.

The largest nature reserve of Russia and Eurasia, the Great Arctic State Nature Reserve and the World Natural Heritage Site of UNESCO - Putorana Reserve in the territory of the Krasnoyarsk Krai is among them.

The Arctic is one of the most fragile ecosystems on the planet. The United Nations Environment Program (UNEP) identifies the following major environmental problems in the Arctic region: climate change and the Arctic ice melting: pollution of the waters of the northern seas by oil and chemical wastes, as well as by marine transport, reduction of the population of the Arctic animals and change of their habitat, climate change and the Arctic ice melting.

The Arctic is a climate forming region of the planet, therefore the state of the environment in the Arctic is, at the same time, an important indicator of global changes that are most significantly manifested in this region.

The Arctic region is full of objects that present a potential radiation hazard. Kola NPP is located here, nuclear-powered surface and underwater ships of the civil fleet and the Navy are located and are repaired in the Arctic, and a considerable part of them

\footnotetext{
Koptseva N.P. (2012). Indigenous Small-Numbered Peoples of the North and Siberia under Conditions of Global Transformations (Case Study of the Krasnoyarsk Territory). 1. Conceptual and Methodological Background of Research. Ethno-Cultural Dynamics of Indigenous Small-Numbered Peoples of the Krasnoyarsk Krai. Krasnoyarsk, Siberian Federal University, 640 p.
} 
is subject to utilization. The objects of irradiated nuclear fuel storage are located on the coasts of the Barents and the White Seas.

The problem of recycling industrial waste that are accumulated around industrial enterprises in huge quantities is extremely acute for the Arctic zone. Due to the peculiarities of the air masses circulation in the Arctic, pollutants, gas and aerosol admixtures are accumulated in its atmosphere.

The major environmental threats in the Arctic zone of Russia are: increased pollution and degradation of the natural environment components under conditions of growing anthropogenic pressure; waste accumulation; high risks and costs in the process of natural resources development; global climate change and its impact on the permafrost zone; the development of hazardous hydrometeorological, ice and other natural processes, increasing the risk and damage from these processes.

From 2012 to 2015 a "big" cleaning up was carried out on Novaya Zemlya and Franz Josef Land to eliminate the environmental damage caused to the Arctic islands in the past decades. During this time, more than 42.000 tons of various types of waste were removed from the territory of the Russian Arctic National Park, 349 hectares of disturbed lands were rehabilitated.

The main measures for the implementation of the state policy in the sphere of ensuring environmental safety in the Arctic zone of the Russian Federation are: the establishment of special regimes for the use of natural resources and environmental protection, including monitoring of its pollution; natural landscapes restoration, utilization of toxic industrial wastes and ensuring chemical safety, primarily in the densely inhabited areas. A comprehensive plan for the implementation of the Climate Doctrine of the Russian Federation for the period up to 2020 was approved by the Decree of the Government of the Russian Federation of April 25, 2011.

Despite the obvious significance of the Russian Arctic, the socio-economic, demographic and environmental situation in this region remains very complex, and the civil and military infrastructures necessary to implement the strategic opportunities of the region in such areas as the development of its natural resources and the international transport system do not correspond either to current, or, all the more, to the future needs ${ }^{1}$.

Kartamysheva, N.S., Biekenova, A.S. (2015). The Arctic and Development of the Arctic Zone, In Molodoi uchenyi [Young Scientist], 13, 333-337. Available at: https://moluch.ru/archive/93/20714/ (Accessed: 06.05.2018). 


\section{Development of the Arctic Zone of the Russian Federation Under Conditions of Global Transformations}

According to the "Basics of the State Policy of the Russian Federation in the Arctic for the Period till 2020 and for a Further Perspective" of 2008 and the "The Development Strategy of the Arctic Zone of the Russian Federation and National Security for the Period up to 2020" of 2013, the key factors affecting social and economic development of the Arctic zone of the Russian Federation, are:

a) extreme natural and climatic conditions, including low air temperatures, strong winds and ice cover in the Arctic seas;

b) focal character of the industrial and economic development of the territories and low population density;

c) remoteness from the main industrial centers, high resource consumption and dependence of economic activity and life-support of the population on deliveries of fuel, foodstuffs and essential commodities from other regions of Russia;

d) low stability of ecological systems determining the biological balance and climate of the Earth, and their dependence even on insignificant anthropogenic impacts. ${ }^{1}$

The presence of these factors entails a whole range of risks and threats in the system of social and economic development of the Arctic zone of the Russian Federation. It is necessary to solve a number of problems in the social sphere, the economic sphere, the sphere of science and technology, as well as the sphere of nature management and environmental protection. The removal of tensions in these areas is important for ensuring the sustainable development of the Russian Arctic in the context of global transformations:

a) in the social sphere:

negative demographic trends in most Arctic regions of the Russian Federation, outflow of labor resources (especially highly skilled) to the southern regions of Russia and abroad;

mismatch network of social services and the nature of the dynamics of settlement, including in education, healthcare, culture, physical culture and sports;

critical state of housing and communal services, insufficient supply of population with clean drinking water;

lack of effective training system, the imbalance between demand and supply of labor in the territory and professionally (shortage of workers and engineering professions and a surplus of unneeded specialists, as well as people without vocational training);

\footnotetext{
The Development Strategy of the Arctic Zone of the Russian Federation and National Security for the Period up to 2020 (2013). Available at: http://government.ru/info/18360/
} 
poor quality of life of the small-numbered indigenous peoples of the North, Siberia and the Far East of the Russian Federation living in the Arctic zone of the Russian Federation;

b) in the economic sphere:

the lack of modern Russian technical means and technologies for exploration and development of offshore hydrocarbon fields in the Arctic;

depreciation of fixed assets, particularly transport, industrial and energy infrastructure;

underdevelopment of the basic transport infrastructure, its marine and continental components, aging icebreaking fleet, lack of small aircraft;

high energy consumption and low efficiency of extraction of natural resources, the costs of northern production without effective compensatory mechanisms, low labor productivity;

imbalance in economic development between individual subarctic territories and regions, a significant gap between the leading and depressed areas in terms of development;

insufficient development of navigation, hydrographic and hydrometeorological support of navigation;

lack of permanent complex space monitoring of the Arctic territories and waters, dependence on foreign funds and sources of information management for all activities in the Arctic (including interaction with aircraft and sea vessels);

lack of a modern information and telecommunication infrastructure that enables the provision of communication services to the population and economic entities across the Arctic zone of the Russian Federation;

lack of the energy system development and the irrational structure of generating capacity, high cost of electricity generation and transportation;

c) in the field of science and technology there is a shortage of technical resources and technological capabilities for studying, development and use of the Arctic areas and resources, lack of readiness for the transition to innovative development of the Arctic zone of the Russian Federation;

d) in the sphere of nature management and environmental protection stands out an increase of technological and human impact on the environment with increased probability of reaching its limit values in some areas adjacent to the Russian Federation waters of the Arctic Ocean, as well as in certain regions of the Arctic zone of the Russian Federation, particularly characterized by the presence of adverse areas, potential 
sources of radioactive contamination, and high level of accumulated environmental damage 1 .

The Russian Arctic is a territory that requires bold decisions and innovative approaches. Its specificity makes it necessary to look for new forms, methods and rules for ensuring integrated and sustainable social and economic development in the conditions of global transformations.

\section{Resource Potential and Prospects for the Yenisei Arctic Development}

The Krasnoyarsk Krai is the largest in area Arctic subject in the Russian Federation (about 1095.6 thousand $\mathrm{km}^{2}$ is $46.3 \%$ of the territory of the Krai and $29.5 \%$ of the territory of the Arctic zone of the Russian Federation) $)^{2} .229$ thousand people live in this territory. And if we consider the regions of the Far North and the areas equated to them, that population is 500 thousand people, then this is $89 \%$ of the Krasnoyarsk Krai territory.

Russian politicians and scientists have repeatedly stated that the Krasnoyarsk Krai is a subject of the Russian Federation that most fully represents the basic processes taking place in the country ${ }^{3}$.

The study of the problems and prospects for the development of the Arctic Territories of the Krasnoyarsk Krai should strengthen the interconnection of regional strategic studies with federal policy.

The author identifies the Yenisei Arctic as the object of this research that includes three largest districts of the Krasnoyarsk Krai that have the status of the Arctic zone of Russia: Norilsk urban district, the Taymyr Dolgano-Nenetsk District and Turukhansky District. It also includes Evenkiysky, Severo-Yeniseysky and Yeniseysky municipal districts, as the territories equated to the Far North.

The competitive advantages of the Yenisei Arctic are determined by the availability of strategic resources - non-ferrous metal ores, oil, gas, metallurgical coal, precious

The Development Strategy of the Arctic Zone of the Russian Federation and National Security for the Period up to 2020 (2013). Available at: http://government.ru/info/18360/

2 Shishatsky, N.G., Bryukhanova, E.A., Matveev, A.M. (2018). Problems and Prospects of Development of the Arctic Zone of the Krasnoyarsk Krai, In EKO Vserossiiskii ekonomicheskii zhurnal [All-Russian Economic Journal EKO], 4.

3 Koptseva N.P. (2012). Indigenous Small-Numbered Peoples of the North and Siberia under Conditions of Global Transformations (Case Study of the Krasnoyarsk Territory). 1. Conceptual and Methodological Background of Research. Ethno-Cultural Dynamics of Indigenous Small-Numbered Peoples of the Krasnoyarsk Krai. Krasnoyarsk, Siberian Federal University, 640 p. 
metals and gold, their special importance for sustainable development of the region's economy and demand on the world market.

A powerful production base has been formed in the north of the region. Today, such industrial companies as the Polar Division of MMC Norilsk Nickel, Vankorneft and RN-Shelf-Arctic function in Turukhansk and Taimyr; Vostok Coal and the Arctic Mining Company subsidiary function in Dixon, and Lukoil-Western Siberia on the Taimyr Peninsula.

The Polar Division of PJSC MMC Norilsk Nickel produces more than 90 percent of Russian nickel, more than 40 percent of copper and 98 percent of platinum group metals.

In 2017, the company restored the production of non-ferrous metals as a result of increased capacity utilization after the modernization of the Talnakh concentrator and Nadezhda Metallurgical Plant in the beginning of the year. At the same time, the past year was the first year of the company operation after the closure of the nickel plant, which had a negative impact on the ecological situation in Norilsk.

In 2018 PJSC MMC Norilsk Nickel and LLC Russian Platinum signed an agreement on strategic partnership which implies the creation of a joint venture for the further development of the Norilsk industrial region. The company aims to create one of the world's largest producers of platinum group metals with a production volume of 70100 tons of platinum group metals per year.

In the Turukhansk district, economic activities are conducted by Vankorneft, a subsidiary of Rosneft. The enterprise annually produces more than 22 million tons of oil at the deposits of the Vankor cluster: Vankor, Suzun, Tagulskoe and Lodochnoe. In 2017, 23.5 million tons were produced. Taking into account the commissioning of new deposits Srednebotuobinsky and Yurubucheno-Tokhomsky, by 2025 the total debit is expected to reach 55 million tons per year.

Lukoil-Western Siberia is developing the East Taimyr area. Its forecast resources of oil are 4.5 million tons; of gas -9.3 billion cubic meters, and of condensate -500 thousand tons.

Company RN-Shelf-Arctic performs work on the license area "Hatangsky" in the Taimyr Dolgano-Nenets district. Based on the results of drilling on the Khara-Tumus Peninsula on the shelf of the Khatangsky Bay of the Laptev Sea, the oil reserves were included in the state balance sheet.

The development of the West Taimyr coal-bearing region has begun. VostokCoal and its subsidiary, Arctic Mining Company, are implementing a project to develop one of the world's largest anthracite deposits. 
The coal mined in the Taimyr Coal Basin will be transported to Europe along the Northern Sea Route, which implies the development of the Seaport of Dixon in Taimyr and construction of the coal wharf in the Chaika Seaport.

New subsoil users come to the Taimyr peninsula. Joint-stock company Severnaya Zvezda of AEON corporation is planning to start development of the Syradasai deposit from 2019, including the creation of a coal mine with a capacity of 10 million tons per year, as well as the construction of a seaport, a highway and a concentrating plant.

The vast territory of the Mountainous Taimyr, in the north of the rural settlement of Khatanga is also prospective for development. The total resource potential of the region, based on the results of geological exploration, is estimated at more than 2000 tons of gold. It is necessary to continue geological exploration and licensing of sites, which will lead to new deposits discovery and then, in the future, Mountainous Taimyr can become a major gold mining center, a gold-bearing province.

In 2017 the gold mining enterprises Polyus, Sovrudnik and Drazhny mine produced 62 tons of gold in the Severo-Yeniseysky district. The other gold mining companies of the region produced up to 5 tons of gold. The jointed amount accounted for $1 / 4$ of the total gold output in Russia.

When assessing the endowment of the Yenisei Arctic with forest resources it has been revealed that its share is $63.4 \%\left(7.3\right.$ billion $\left.\mathrm{m}^{3}\right)$ of the total timber stock $(11.5$ billion $\mathrm{m}^{3}$ ) in the Krasnoyarsk Krai.

Promising for development:

Taimyr-Severozemelskaya gold-bearing province;

the world's largest deposit of impact diamonds - Popigai;

the world's largest complex deposit of rare-earth metals is Gulinsky ore massif.

The enormous potential of the Yenisei Arctic development gives an opportunity to consider this region as a locomotive of economic growth of not only the Krasnoyarsk Krai, but Siberia, and the country as a whole.

\section{Conclusion}

Summarizing all of the above, the author agrees with N.G. Shishatsky that further development of the northern territories of the Krasnoyarsk Krai based on the principles of sustainable development (that is, on the basis of a balance of state and private interests, under conditions of the application of the most stringent environmental standards and the use of the most effective resource-saving and environmentally friendly technologies), the implementation of new projects in the mineral raw materials 
and transport, as well as power-generating sectors, the use of resources in the Arctic territories as the basis for the development of high-tech and management innovation, as well as proving a high level and quality of life of the population ${ }^{1}$ will help the Yenisei Arctic to take leading positions not only in Siberia, but also in the Russian Arctic space.

\section{References}

Anderson, D.G. (1996). Bringing Civil Society to an Uncivilised Place, In Civil Society: Challenging Western Models, 99-120.

Anderson, D.G. (2000). Identity and Ecology in Arctic Siberia: The Number one Reindeer Brigade. Oxford University Press.

Ekologicheskie problemy Arktiki i severnykh territorii, mezhvuzovskii sbornik nauchnykh trudov [Ecological Problems of the Arctic and Northern Territories, Interuniversity Collection of Scientific Papers]. (2015). Northern (Arctic) Federal University named after M.V. Lomonosov. Arkhangelsk, N(A)FU, 18, 403 p.

Ermolin, B.V. (1999). Okhraniaemye prirodnye territorii Evropeiskogo Severa Rossii: uchebnoe posobie [Protected Natural Territories of the European North of Russia: Study Guide]. Pomor State University, Department of Geography and Geoecology, Arkhangelsk Regional Department of Public Organization of the AllRussian Order of the Red Banner of Labor Society for the Conservation of Nature, State Committee for Environmental Conservation. Arkhangelsk, PSU, 112 p.

Forsyth, J. (1994). A History of the Peoples of Siberia: Russia's North Asian Colony 1581-1990. Cambridge University Press, 445 p.

Vtoroi otsenochnyi doklad Rosgidrometa ob izmeneniiakh klimata i ikh posledstviiakh na territorii Rossiiskoi Federatsii: tekhnicheskoe resume [Second Assessment Report of Roshydromet on Climate Change and its Consequences in the Russian Federation: Technical Summary] (2014). The Federal Service for Hydrometeorology and Environmental Monitoring of Russia (Roshydromet), Moscow, Roshydromet, 93 p.

Global Climatic Processes and their Effects on Ecosystems of Arctic and Subarctic Regions: Proceedings of the International Scientific Conference (Murmansk, 9-11 November) (2011). Kola Scientific Centre of the Russian Academy of Sciences. Murmansk Marine Biological Institute. Apatity, KSC RAS, 219 p.

Shishatsky, N.G., Bryukhanova, E.A., Matveev, A.M. (2018). Problems and Prospects of Development of the Arctic Zone of the Krasnoyarsk Krai, In EKO Vserossiiskii ekonomicheskii zhurnal [All-Russian Economic Journal EKO], 4. 
Kartamysheva, N.S., Biekenova, A.S. (2015). Arktika i razvitie arkticheskoi zony [The Arctic and Development of the Arctic Zone], In Molodoi uchenyi [Young Scientist], 13, 333-337. Available at: https://moluch.ru/archive/93/20714/ (Accessed: 06.05.2018).

Koptseva, N.P. (2012). Korennye malochislennye narody Severa i Sibiri v usloviiakh global'nykh transformatsii (na materiale Krasnoiarskogo kraia). Ch. 1 Kontseptual'nye $i$ metodologicheskie osnovy issledovaniia. Etnokul'turnaia dinamika korennykh malochislennykh narodov Krasnoiarskogo kraia [Indigenous Small-Numbered Peoples of the North and Siberia under Conditions of Global Transformations (Case Study of the Krasnoyarsk Territory). 1. Conceptual and Methodological Background of Research. Ethno-Cultural Dynamics of Indigenous Small-Numbered Peoples of the Krasnoyarsk Krai]. Krasnoyarsk, Siberian Federal University, 640 p.

Korolev, V.I. (2014). Voenno-morskaia deiatel'nost' Rossii v Arktike [Naval Activity of Russia in the Arctic], In Tr. nauch.-issled. otd. In-ta voen. Istorii [Proc. of Scien. and Res. Institute of Military History], Vol. 9, Book 2, Obespechenie natsional'nykh interesov Rossii v Arktike [Securing Russia's National Interests in the Arctic]. SPb, Politekhnica-servis.

Komfortnaia sreda obitaniia cheloveka v Arktike. Ekspertnaia deklaratsiia KOMFORTNAYA ARKTIKA [Comfortable Living Environment in the Arctic. Expert Declaration COMFORTABLE ARCTIC] (2018). In Krasnoyarskii ekonomicheskii forum [Krasnoyarsk Economic Forum]. Available at: http://porarctic.ru/proyektekspertnoy-deklaratsii-komfortnaya-arktika/

Lukin, Yu.F. (2010). Velikii peredel Arktiki [Great Redistribution of the Arctic]. Arkhangelsk, N(A)FU, 400 p.

New Edition of the State Program "Socio-Economic Development of the Arctic Zone of the Russian Federation" (2017). Available at: http://government.ru/docs/29164/

On the Continental Shelf of the Russian Federation. Available at: https://210fz.ru/ fz-187-o-kontinentalnom-shelfe/

On the Mainland Territories of the Arctic Zone of the Russian Federation. Available at: http:/www.consultant.ru/document/cons_doc_LAW_162553/

On the Approval of the Plan for the Implementation in 2016-2025 of the Concept of Sustainable Development of Indigenous Peoples of the North, Siberia and the Far East (2016). Available at: http://government.ru/docs/24308/

Osnovy gosudarstvennoi politiki Rossiiskoi Federatsii v Arktike na period do 2020 goda i dal'neishuiu perspektivu [Basics of the State Policy of the Russian Federation in the Arctic for the Period till 2020 and for a Further Perspective]. Available at: http:// www.consultant.ru/document/cons_doc_LAW_119442/ 
Pavlenko, V.I. (2013). Arkticheskaia zona Rossiiskoi Federatsii v sisteme obespecheniia natsional'nykh interesov strany [The Arctic Zone of the Russian Federation in the System of Securing National Interests of the Country], In Arktika: Ekologiia i Ekonomika [The Arctic: Ecology and Economics], 4 (12), 18.

Ponomarev, V. (2013). Sabettu "raspechatali" [Sabetta Was "Opened"], In YamalArktika [YamalArctics], 2 (3).

Ruksha, V.V., Belkin, M.S., Smirnov, A.A., Arutunyan, V.G. (2015). Problemy Severnogo morskogo puti [Problems of the Northern Sea Route], Struktura i dinamika gruzoperevozok po Severnomu morskomu puti: istoriia, nastoiashchee i perspektivy [Structure and Dynamics of Cargo Transportation along the Northern Sea Route: History, Present and Prospects], In Arktika: Ekologiia i Ekonomika [The Arctic: Ecology and Economics], 4 (20).

Shishatsky, N.G., Bryukhanova, E.A., Matveev, A.M. (2018). Problemy i perspektivy razvitiia Arkticheskoi zony Krasnoiarskogo kraia [Problems and Prospects of Development of the Arctic Zone of the Krasnoyarsk Krai], In EKO Vserossiiskii ekonomicheskii zhurnal [All-Russian Economic Journal ECO], 4.

St. Petersburg State Polytechnical University Journal (2016). Humanities and Social Sciences, 4 (255).

Strategii razvitiia Arkticheskoi zony Rossiiskoi Federatsii $i$ obespecheniia natsional'noi bezopasnosti na period do 2020 goda [The Development Strategy of the Arctic Zone of the Russian Federation and National Security for the Period up to 2020]. Available at: http:/government.ru/info/18360/

The National Security Strategy of the Russian Federation. Available at: http:// www.consultant.ru/document/cons_doc_LAW_191669/

Vystuplenie Vladimira Putina na Mezhdunarodnom forume "Arktika - territoriia dialoga" 2017 [Vladimir Putin's Speech at "The Arctic: Territory of Dialogue" International Forum 2017]. Available at: http://forumarctica.ru/news/vystuplenievladimira-putina-na-mezhdunarodnom-forume-arktika-territoriya-dialoga/

Zhilinsky, A.A. (1919). Krainii Sever evropeiskoi Rossii. Arkhangel'skaia guberniia [The Far North of European Russia. Arkhangelsk Province]. Petrograd, Typo-Lithography of the North-Zaadny District of Railways, 296 p.

Zapovedniki, zakazniki i natsional'nye parki Arktiki [Reserves, Sanctuaries and National Parks of the Arctic]. Available at: http://sevprostor.ru/poleznoe-interesnoe/ arctic/617-zapovedniki-nacionalnye-parki-arktiki 


\section{Современные тенденции, проблемы и перспективы развития Енисейской Арктики}

О.В. Шулепова

Сибирский федеральный университет Россия, 660041, Красноярск, пр. Свободный, 79

Статья посвящена анализу основных исследований, законодательной базы и тенденций, связанных с пространственным развитием Арктической зоны Красноярского края, одного из важнейших стратегических регионов Российской Федерации. Проанализировано большое количество современных академических исследований, имеюших отношение к важнейшим социально-культурным и социально-экономическим факторам, обуславливающим развитие Енисейской Арктики. Понятие «Енисейская Арктика» начинает разрабатьвваться, по сути, впервые. Временной диапазон анализируемой научной и нормативной литературы - 2008-2018 г2. Тем самым в статье представлены наиболее актуальные материалы, которые связаны с тенденциями развития одного из важнейших проектов современного Красноярского края-Енисейской Сибирью.

Цель исследования - выявить векторы академической науки, связанные с Енисейской Сибирью, обосновать использование кониепта «Енисейская Сибирь».

Статья может быть интересна для широкого круга современных исследователей, она затрагивает не только такую область науки, как культурология, но и несколько других областей научных дисциилин, таких как экономика, политология и социология. В заключение делаются выводы о наиболее перспективных линиях исследования Енисейской Арктики, раскрываются наиболее важные концептуальные и методологические подходы, которые могут быть использованы для решения академических проблем.

Ключевые слова: Енисейская Сибирь, Енисейская Арктика, конщепџии, методы, академические исследования, правовая база.

Научная специальность: 24.00.00 - культурология. 